
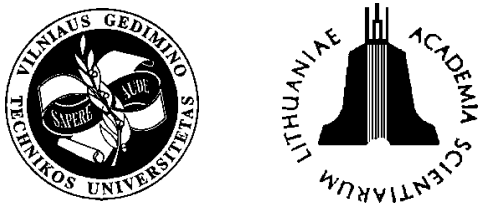

JOURNAL OF CIVIL ENGINEERING AND MANAGEMENT

http:/www.vtu.lt/english/editions

2004, Vol X, No 1, 45-49

\title{
EXPERIMENTAL BEHAVIOUR OF COMPOSITE GIRDERS WITH STEEL UNDULATING WEB AND THIN-WALLED SHEAR CONNECTORS HILTI STRIPCON
}

\author{
Jan Motak ${ }^{1}$, Josef Machacek ${ }^{2}$ \\ Czech Technical University in Prague, Faculty of Civil Engineering, Thakurova 7, 16629 Praha, Czech Republic \\ E-mails:1'motak@fsv.cvut.cz; ${ }^{2}$ machacek@fsv.cvut.cz
}

Received 20 Jan 2004; accepted 20 Feb 2004

\begin{abstract}
Two tests of real-size composite steel and concrete girders are described. The girders had spans 7,5 m, thinwalled undulating webs (WT girders) and concrete deck 120/1500 mm concreted into profile steel sheeting TR 60/235/0,75. Thin-walled shear connectors Hilti Stripcon were used and fastened via powder actuated fasteners. Setup of the tests, relevant instrumentation and measuring procedure are presented. The girder tests supplemented large series of push tests of connectors Stripcon performed at CTU in Prague. One of the composite girders was designed with full-shear connection while the second one with extremely low partial shear connection (44\%). Simple preliminary linear calculations proved that experimental strength capacities of the girders are in good agreement with the calculated values, however, the deflection are due to flexibility of the connectors higher. Buckling shear capacity of the undulating webs in both tests was higher than shear at collapse of the girders. Another test dealing with interaction of web buckling in shear and Stripcon shear connection is under progress. Comparison of theoretical and experimental results is performed and recommendations for practical design are presented.
\end{abstract}

Keywords: composite girder, shear connector, Stripcon, undulating web, powder actuated fastener, test.

\section{Introduction}

Novel structural forms in composite steel and concrete structures enlarge material base of modern structures and pertain to progressive trends in structural design. Recently some highly efficient elements were introduced into practice, namely steel girders with undulating web produced by Zeman $+\mathrm{Co} \mathrm{GmbH}$ (Wien) (Fig 1) [1] and thin-walled shear connectors developed by Hilti Corporation [2], which are fastened to beam flange by powder actuated fasteners and called Ribcon or Stripcon (Fig 2).

Stripcon shear connector is suitable especially for use with metal decking whose waves run perpendicularly to the beam axis. The connector is made of cold formed steel strip of $80 \mathrm{~mm}$ width, with a shape corresponding
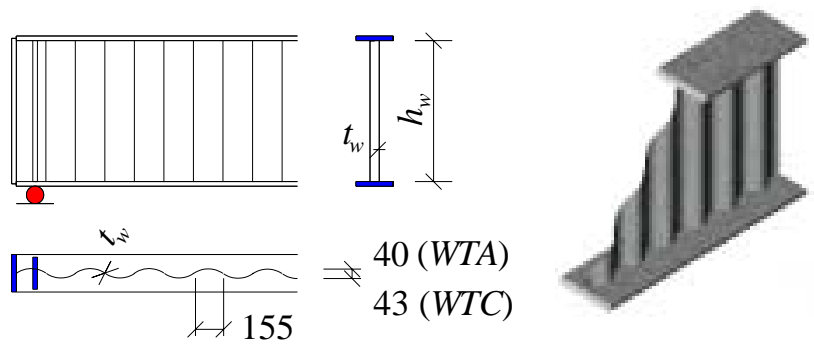

Fig 1. $W T$ girders

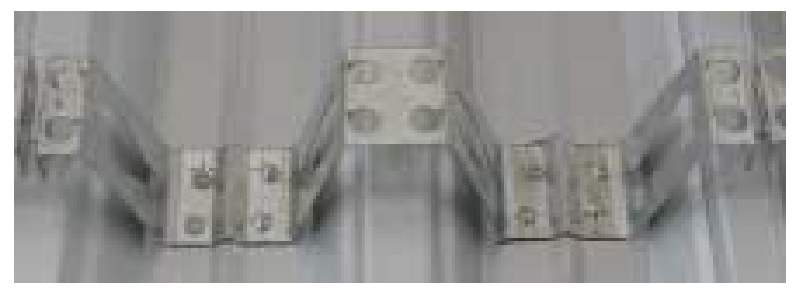

Fig 2. Shear connector Stripcon

to the wave of the trapezoidal sheeting used as a formwork, the wave of the connector being, however, higher. Holes are cut in the connector for penetration of concrete and the connector is fastened to a beam by 4 fired nails in its each valley (Fig 3).

Both newly developed connectors (Ribcon and Stripcon) are certified for use in Czech Republic in accordance with ENV 1994-1-1 (Eurocode 4) based on research $[3,4]$ resulting in design strength of the connectors. As for Stripcon (made of steel with yield point $f_{y}=300$ to $400 \mathrm{MPa}$ ) the following characteristic shear strength and partial safety factor were derived:

$$
P_{R k}=18,4 \mathrm{kN}
$$

per one nail Hilti ENPH2-21-L1 (marked \#515693), ie $147,2 \mathrm{kN}$ per one connector having 8 nails,

$$
\gamma_{v}=1,3
$$



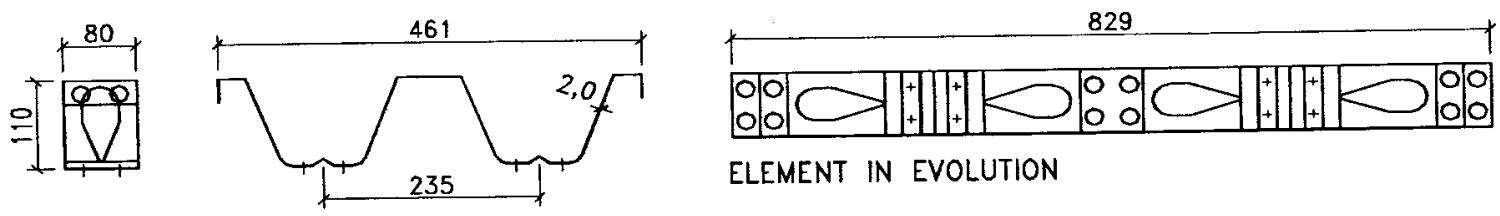

ELEMENT IN EVOLUTION

Fig 3. Stripcon shear connector (side view, cross-section, element in evolution)

The values are applicable for concrete characteristic strength $f_{c k}=20$ to $45 \mathrm{MPa}$ and the shear connector is classified as ductile in accordance with Eurocode 4.

While some further research of girders with undulating webs and Stripcon shear connectors is under way [5], no mutual use of both elements was realised up to now. This paper describes real size experiments for combined use of both of them in composition shown in Fig 4. The investigation covers both full and partial shear connection to analyse full range of the use in structures. The possible application is envisaged in floor beams of multi-story buildings having larger spans (>6 m) as contemporarily required for administrative buildings.

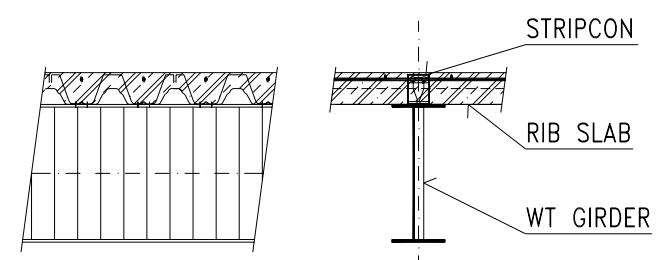

Fig 4. View and cross-section of the composite beam

\section{Experimental investigation}

The composite girders under investigation consisted of steel girder with undulating web denominated $W T$ (WTC for the first test, with flange dimensions $200 \times 10$ $\mathrm{mm}$ and web 500x3,0, WTB for the second test, with the same flanges but web $500 \times 2,5 \mathrm{~mm}$ ) and concrete slab
$1500 \times 120 \mathrm{~mm}$. More details on $W T$ girders, practical design and strengths in shear, local loading and fatigue may be found in $[1,4]$. The slab was concreted into thin-walled trapezoidal sheeting of Vikam TR60/2350,75 made of steel S320G and acting as permanent formwork. The girders were considered as secondary floor beams. Therefore, the ribs of the sheeting were orthogonal to the beams with its wider ribs headed to upper surface of the slab. The slab was reinforced by minimal welded mesh reinforcement as required by Eurocode 2. The shear connectors Stripcon TR60/235 (made of steel S280GD) were supplied by Hilti Corporation and produced in Czech Republic. Each connector was fastened to the beam flange through the sheeting by 8 nails Hilti ENPH2-21-L1 [6].

The finished tests comprise two static experiments carried out in Structural laboratory of Faculty of Civil Engineering of CTU in Prague. The girders denominated EX1 and EX2 with span of $7500 \mathrm{~mm}$ were loaded in bending. The two tests differ in level of shear connection.

Girder EX1 was designed with full-shear connection with level of $\mu=117 \%$ (were $\mu=100 \%$ matches the connection corresponding to plastic capacity of the composite beam cross section). In this case the Stripcon connectors were placed over each wave of the sheeting.

Girder EX2 had extremely low level of shear connection corresponding $\mu=44 \%$. In this case there were 4 ribs of the sheeting free between the connectors (with a free space of $949 \mathrm{~mm}$ between the connectors having length of $461 \mathrm{~mm}$ ). The geometry of the girder and arrangement of the tests are shown in Figs 5, 6.

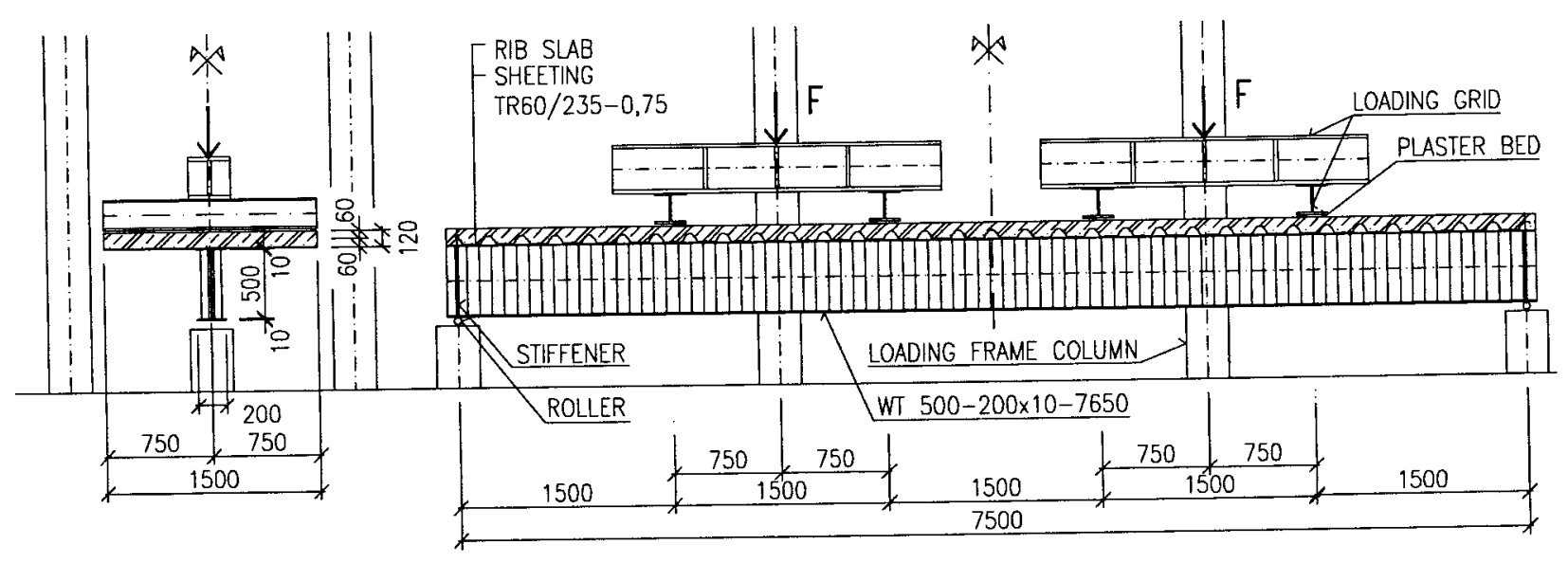

Fig 5. Set up of the tests EX1 and EX2 

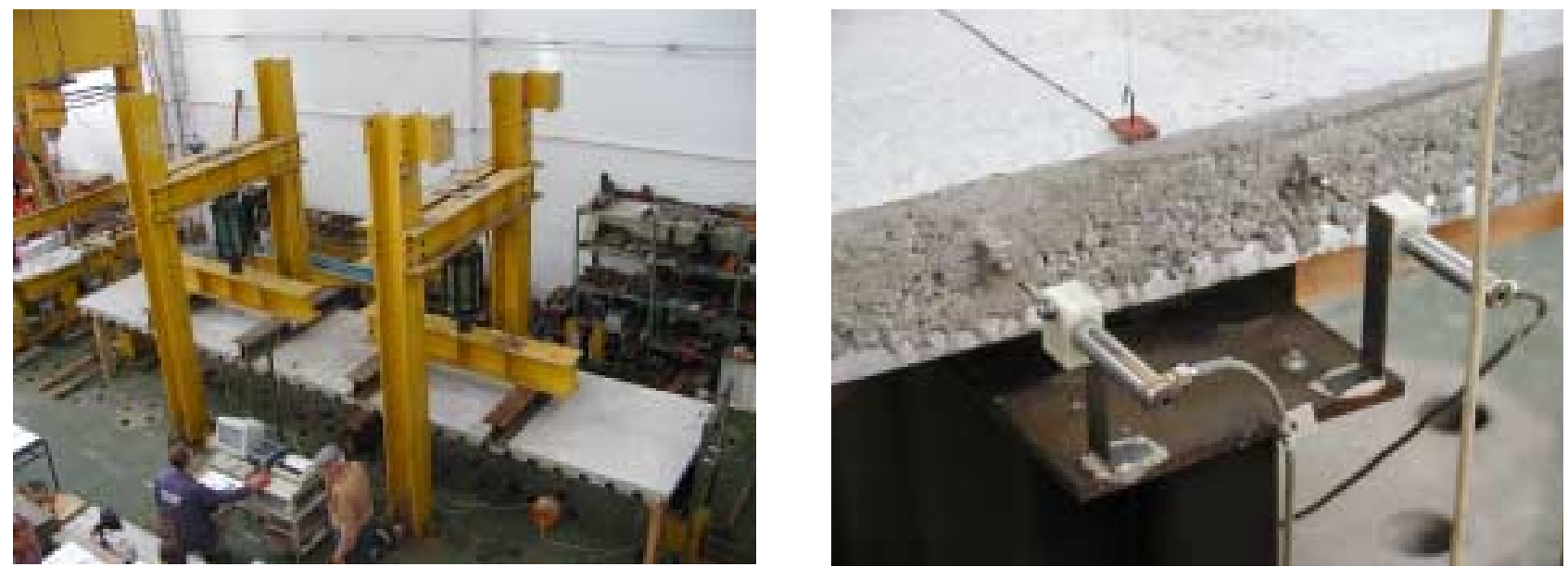

Fig 6. Testing in laboratory of CTU in Prague: General set-up (left), slip measurement (right)

The loading was realised through pair of hydraulic load cells PZ60 connected in parallel way and placed in the fifth span. The loading of the first test (EX1) was governed by the load while in the second test (EX2) by deflection of the central load cell. The loading procedure followed the same two-phase pattern. In the first phase, given by elastic behaviour, each loading was followed by unloading. In the second phase, plastic one, the loading continued after settling down both of the deflections and stresses of the current loading up to the collapse.

Deflections and strains were monitored in 5 crosssections (longitudinally in both ends of the beam, $L / 4$, $L / 2,3 L / 4)$. Within cross-sections the transducers and strain gauges were placed symmetrically on bottom fibres of bottom flange of the steel girder, on bottom fibres of upper flange of the steel girder and upper fibres of the slab. Other transducers of inductive type IWT302 were used to monitor slip between the concrete slab and steel girder at span ends (Fig 6).

The data of electric transducers and strain gauges Mikrotechna C120 for steel and HBM 100/120 LY 41 for concrete parts were treated by data proessor HBM UPM 60 and PC.

\section{Evaluation of results}

During testing the basic material characteristics for steel (flanges and webs) and concrete were evaluated. The average received values are given in Table 1.
Table 1. Material characteristics

\begin{tabular}{c|c|c|c|c}
\hline \multirow{2}{*}{ Girder } & \multicolumn{2}{|c|}{ Concrete } & \multicolumn{2}{c}{ Steel } \\
\cline { 2 - 5 } & $f_{\text {c.cube }}$ & $E_{c}$ & $f_{y . f} / f_{\text {y.w }}$ & $E_{a . f} / E_{a . w}$ \\
\cline { 2 - 5 } & {$[\mathrm{MPa}]$} & {$[\mathrm{GPa}]$} & {$[\mathrm{MPa}]$} & {$[\mathrm{GPa}]$} \\
\hline EX1 & 25,6 & 31,2 & $296,2 / 314,5$ & $210 / 208,3$ \\
\hline EX2 & 25,4 & 23,0 & $296,2 / 314,5$ & $210 / 208,3$ \\
\hline
\end{tabular}

Summary of the results received from simple calculations in accordance with Eurocode 4 [7] and test results of both girders are presented in Table 2 .

In the table is given level of shear connection

$$
\mu=N / N_{f}
$$

which corresponds to real placed number of shear connectors $N$ and numbers $N_{f}$ required for full connection. Calculated plastic load capacity $F_{p l . R}$ is given for the first test EX1, while for partial shear connection in the second one EX2 the value of $F_{R}$ corresponding to capacity of shear connection is presented. Other values $F_{e l . R}$ and $\delta_{R}$ are elastic values of loading and deflection at mid-span corresponding to yielding of bottom fibres of steel girder.

Deflection of the girders at mid span and slip between steel and concrete part at girder ends resulting from tests are shown in Fig 7.

Test EX1 was terminated after reaching full redistribution of stresses corresponding to calculated plastic moment capacity. The deflection was large, nevertheless no buckling of undulating web was monitored as the shear capacity was significantly higher $\left(F_{b}=270,2 \mathrm{kN}\right)$ in comparison to shear at collapse $(F=190,3 \mathrm{kN})($ Fig 8$)$.

Table 2. Test results and comparison with calculation in accordance with [7]

\begin{tabular}{c|c|c|c|c|c|c|c|c|c}
\hline \multirow{2}{*}{ Girder } & \multicolumn{4}{|c|}{ Calculation (R values) } & \multicolumn{4}{c}{ Test } \\
\cline { 2 - 27 } & $N / N_{f}$ & $F_{p l . R}$ & $F_{R}$ & $F_{e l . R}$ & $\delta_{R}$ & $F_{e l}$ & $\delta$ & $\max F$ & $\max \delta$ \\
\cline { 2 - 12 } & {$[-]$} & {$[\mathrm{kN}]$} & {$[\mathrm{kN}]$} & {$[\mathrm{kN}]$} & {$[\mathrm{mm}]$} & {$[\mathrm{kN}]$} & {$[\mathrm{mm}]$} & {$[\mathrm{kN}]$} & {$[\mathrm{mm}]$} \\
\hline EX1 & 1,17 & 189,6 & - & 158,6 & 20,2 & 139,5 & 18,5 & 190,3 & 173,5 \\
\hline EX2 & 0,44 & - & 160,9 & 157,2 & 26,6 & 149,8 & $36-41,8$ & 154,0 & 100,3 \\
\hline
\end{tabular}




\section{Test EX1}
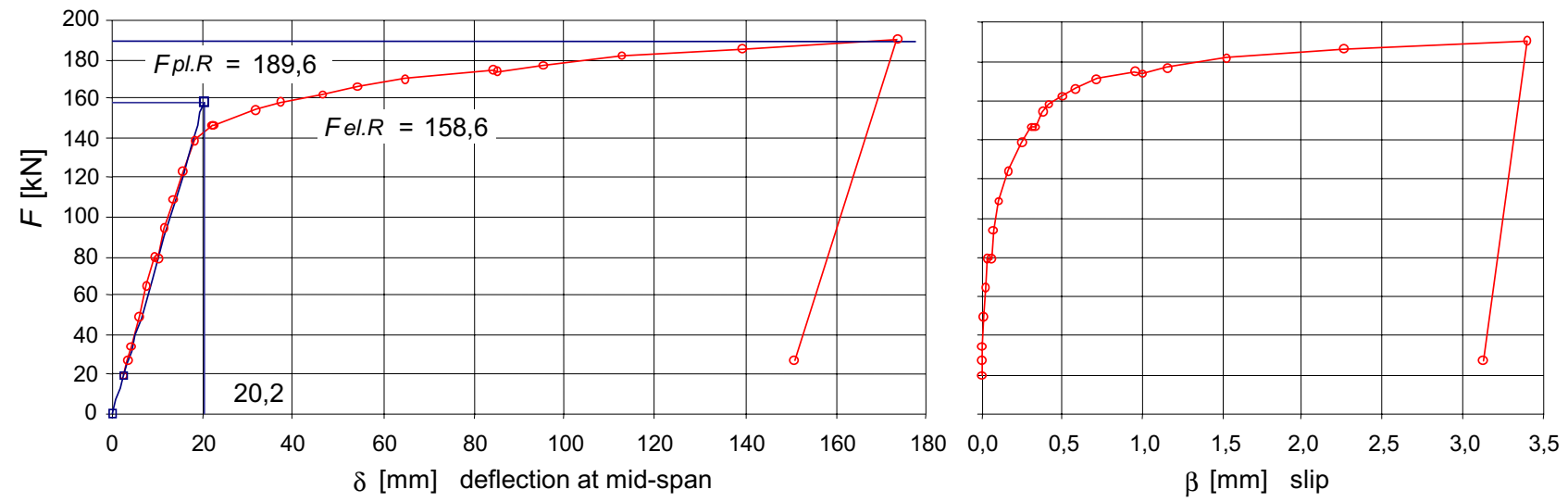

\section{Test EX2}
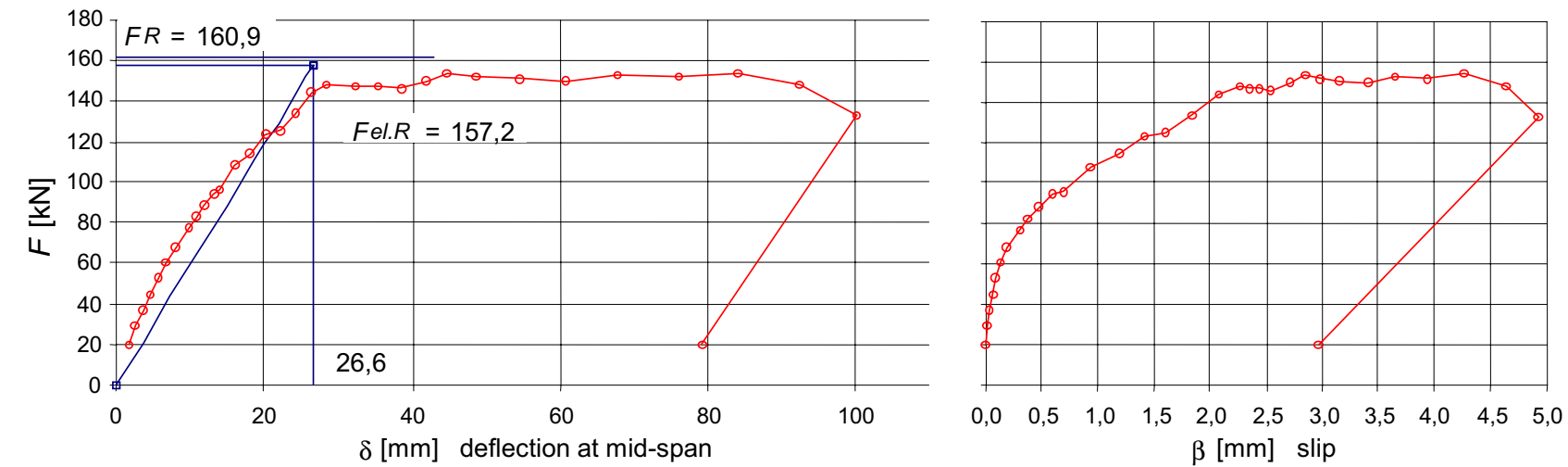

Fig 7. Tests EX1 and EX2: Deflection at mid span (left), slip between concrete slab and steel (right) and comparison with Eurocode 4 [7] calculations (R values)

Test EX2 terminated due to extreme deflection after approaching the calculated capacity of the partial shear connection. As follows from Fig 7, the slip grew up rapidly after the load reached approx $50 \%$ of its theoretical elastic value. Both very low partial connection and ductile connectors are sources of this behaviour. Again, buckling of undulating web or its interaction with action of shear connectors did not take place.

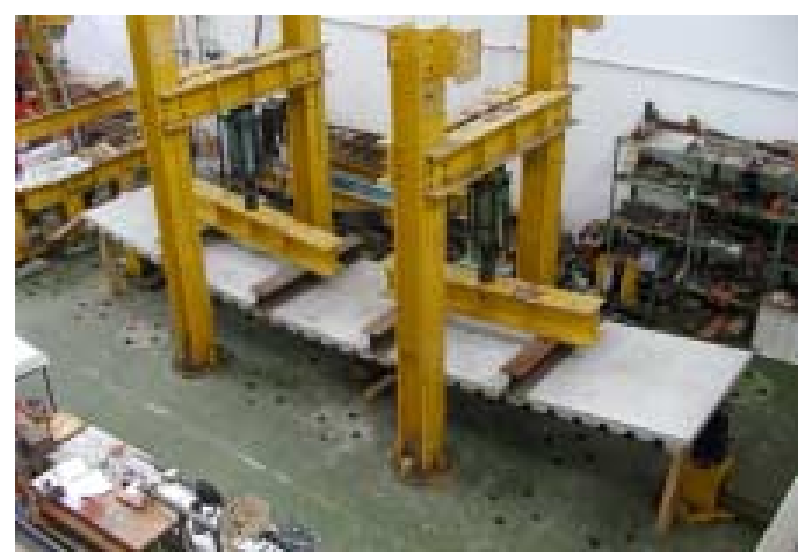

Fig 8. Girder in test EX1 after collapse
In the case of full-shear connection the theoretical plastic strength of the girder agrees well with the test collapse capacity. However, the measured deflection at mid-span for value of theoretical elastic loading is roughly double in comparison with the calculated one. The strong non-linearity of deflection appears after reaching approximately $80 \%$ of the theoretical elastic loading. This behaviour corresponds to distribution of slip between slab and steel girder (Fig 7).

In the case of partial shear connection $(\mu=44 \%)$ the collapse loading reached only $95 \%$ of the theoretical shear connection capacity (critical for this case). Because of proximity of girder elastic strength and calculated capacity of partial shear connection a large slip between the slab and steel girder (with following collapse of the shear connection (Fig 9) appeared accompanied with extreme deflection of the girder. The measured deflection is in agreement with the elastic calculated one until reaching roughly $75 \%$ of its maximum elastic value (Fig 7). 


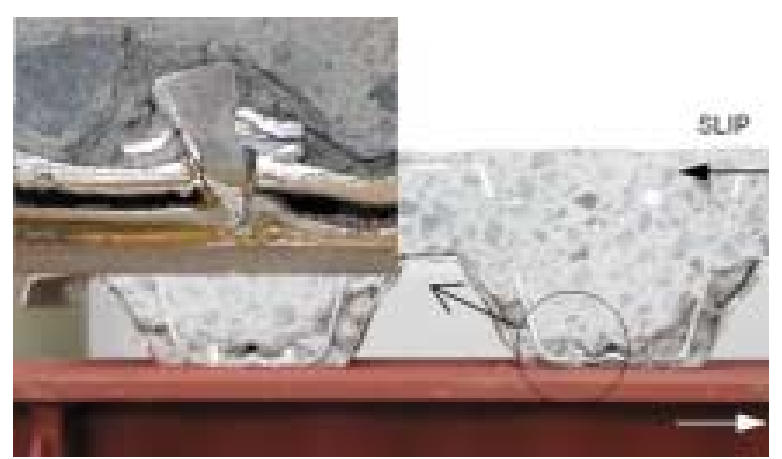

Fig 9. Longitudinal section of the concrete slab at the end of the girder (diamond cutting) and nail's residual deformation in detail

\section{Conclusion}

The experimental investigation and preliminary evaluation of the results proved practical applicability of the new progressive composite girder having shear connectors Hilti Stripcon (Fig 10) and steel girders with undulating web.

The use of connectors Stripcon in composite girders loaded in bending, however, resulted into much more ductile behaviour in comparison with other traditional connectors (welded headed studs, Hilti brackets or perforated shear connector [8]). While the strength of such girder corresponded well to common Standard design, the deflection was larger due to ductility and slip in the shear connection. The elastic calculation of deflections for the tested girder with full-shear connection was corrected up to $80 \%$ of the elastic strength of the girder, while the real maximum deflection value for the elastic girder strength was roughly double to the commonly calculated one. In case of a tested girder with partial shear connection the similar conclusion was valid up to $75 \%$ of the elastic strength of the girder.

Full evaluation of the results and comparison with numerical FE analysis together with parametric study of these composite girders will be presented later.

Another test of a similar composite girder with a shorter span and leading to interaction of buckling of the undulating web and partial shear connection is under process.

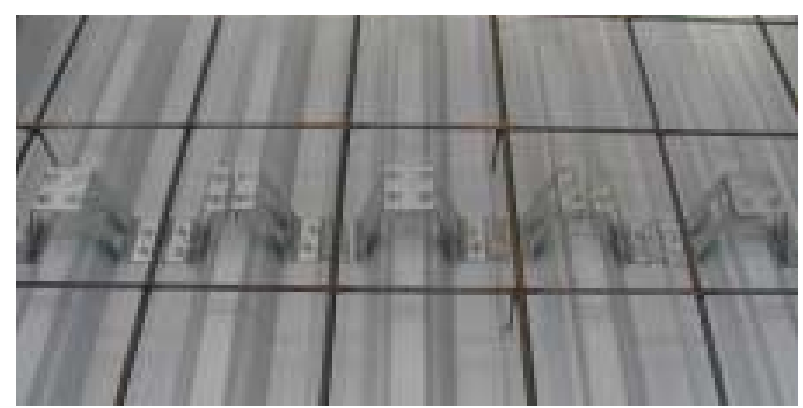

Fig 10. Shear connectors Hilti Stripcon fastened to the steel beam before concreting

\section{Acknowledgement}

This work was carried out at the Dept of Steel Structures and Experimental Centre of CTU in Prague under support of grant by the Czech Grant Agency GACR No 103/02/0008. Investigation was also financially supported by grant of the Czech Ministry of Education MSM 210000001. Thanks are due to companies Hilti Corporation and Kovove profily Ltd for sponsorship.

\section{References}

1. Machacek, J.; Tuma, M. Fatigue of girders with undulating webs. In: Proc Steel Structures, Eurostee. Coimbra: 2002, p. 523-532.

2. Fontana, M.; Beck, H. Novel shear rib connectors with powder actuated fasteners. In: Proc of Conf. Composite Construction in Steel and Concrete IV. Banff: 2000, p. 426437.

3. Studnicka, J.; Machacek, J.; Bouska, P. Shear connectors for composite steel and concrete beams. In: Proc Scientific Session VSU, Vol 1. Sofia: May 2001, p. 60-65.

4. Studnicka, J.; Machacek, J. Shear connectors for composite steel and concrete structures. Structural horizon (Stavebni obzor), Vol 10, No 7, 2001, p. 193-199.

5. Machacek, J.; Tuma, M.: Fatigue of girders with undulating webs under moving local loading. In: Proc $2^{\text {nd }}$ Int Conf Struct. Eng. Mech. Comp. (SEMC 2004), Cape Town, July 2004 (in press).

6. Hilti Designers Manual. 2003. http://www2.hilti.com/cz/

7. prEN 1994-1-1 Design of composite steel and concrete structures. Part 1.1, General rules and rules for buildings. Final Draft, CEN, 2002.

8. Machacek, J.; Studnicka, J. Perforated shear connectors. Steel and Composite Structures, Vol 2, No 1, 2002, p. 5166. 